\title{
AN EMPIRICAL INVESTIGATION OF PROCUREMENT TRENDS AND PARTNERSHIP MANAGEMENT IN FM SERVICES - A FINNISH SURVEY
}

\author{
Tero LEHTONEN ${ }^{1}$ and Anssi SALONEN ${ }^{2}$ \\ 1 CEM Facility Services Research, Helsinki University of Technology, P.O. Box 9800, FI-02015 \\ TKK, Finland \\ Tel. +358 40565 5389; E-mail: tero.t.lehtonen@tkk.fi \\ 2 SATO Corporation, P.O. Box 501, FI-00610 Helsinki, Finland \\ Tel. +358 40514 6181; E-mail: anssi.salonen@sato.fi
}

Received 8 August 2005; accepted 18 October 2005

\begin{abstract}
The aim of this paper is to review procurement trends of facilities management (FM) services and to describe the partnership control mechanisms that contribute to the success of FM partnerships. The investigation is based on a questionnaire survey, which was carried out in Finland. It was found that a transition - similar to those in other industries - towards closer relationships and bigger purchase entities is taking place also in the FM context. In most cases, the choice of the partnering approach is related to developing wider service packages. When implementing partnering relationships, the task of top management is to provide the shared values and visions. Having established these in the organisation, top management does not seem to have any significant role in relationship management. During the ongoing partnership, the operational level runs the daily initiative, development and problem solving based on ad hoc procedures.
\end{abstract}

KEYWORDS: Procurement; Relationship management; Partnering relations; Facilities management services; Finnish survey

\section{INTRODUCTION}

Despite the growing trend towards using supply chain- and relationship management as means of creating and maintaining effective buyer-supplier relations, the literature on the subject is deficient in some crucial ways. When examining the studies intended to promote knowledge on how to effectively operate in business markets and to manage relationships, one sector - business services - may be distinguished as lacking attention (e.g. Sheth and Sharma, 1997; Ellram et al., 2004; van der Valk et al., 2005).

The examples and models used in publications tend to centre on the manufacturing sec- tor and toward the physical transferring of goods. At the same time, services generally take up a growing proportion of organisations' purchasing expenditure, and the role of purchasing within the organisation is changing: purchasing as a function is becoming more strategic (Macbeth, 1994; Arnold, 2000), with a smaller number of highly qualified buyers. Consequently, the strategic processes of the supply chain and relationship management are replacing the traditional function of purchasing that focuses only on the efficient management of the workflow of goods and services supporting the manufacturing activities of the firm (Cousins, 2002). These transformations have created new challenges. Since the forma-

International Journal of Strategic Property Management

ISSN 1648-715X print / ISSN 1648-9179 online (C) 2006 Vilnius Gediminas Technical University

http://www.ijspm.vgtu.lt 
tion and maintenance of closer relationships, such as partnerships, are costly and time-consuming processes (Virolainen, 1998; Lambert and Knemeyer, 2004), companies need to understand more thoroughly the likely nature of the relationships. Similarly, it is increasingly important to know when it is worthwhile to choose a partnering approach, and how partnering relations should be structured and managed. Based on this, partnerships in the manufacturing sector have been a popular subject in the fields of both industrial practice and academic research (e.g. Ellram, 1991; Landeros et al., 1995).

Because services are usually produced in an ongoing buyer-seller interaction (Grönroos, 2000 ), the importance of relationship issues is emphasised. In addition, as the process of purchasing services has been found to be more complex than the process of purchasing goods (Fitzsimmons et al., 1998; Smeltzer and Ogden, 2002), there is a need for research that sheds light on partnership sourcing in business services. The aim of this paper is to establish a deeper understanding of the above-mentioned issues in the area of facilities management (FM) services. When comparing FM services to other business services, the essential characteristic that distinguishes them from other business services is that they are delivered on the premises of clients (Bröchner, 2001).

The aim of this study is to review the procurement trends of FM services in Finland and to validate the partnership control mechanisms that contribute to the success of FM partnerships. As well as contributing to the relationship management literature, this study may be beneficial to both FM service providers and buyers in terms of formulating successful relationships and improving performance and efficiency in partnering relations. This study also provides a process review of the ongoing transition taking place within the purchasing of FM services in order to better understand the causes of the transition.

\section{FM AS A BUSINESS SERVICE}

FM services are an important part of the business service sector. From the cost perspective, the FM budget of an organisation may account for $30-40 \%$ of the outlay, being second in cost only to payroll (Bon et al., 1998; Amaratunga et al., 2000). The importance of FM can also be seen from other perspectives. According to Amaratunga and Baldry (2002), FM is seen as being able to contribute to the performance of organisations in many ways and has, for example, an effect on strategy, culture, control of resources, service delivery, supply chain management and, perhaps most importantly, the management of change. Other researchers illustrate the significance of facilities performance for organisational success based on environmental differentiation as a source of competitive advantage and environmental influence on human/organisational performance (e.g. Balch, 1994; Gajendran and Sabaratnam, 2002). The relative importance of different business services may differ across sectors, industries and individual companies. However, all companies need a workplace (i.e. a physical place and related services) in order to carry out their activities. Fearon and Bales (1995) note that FM services is the most important service category in terms of volume.

Facilities management is an umbrella term under which a wide range of property- and user-related functions may be brought together for the benefit of the organisation as a whole as well as its employees (Amaratunga et al., 2000 ). In practice, FM can cover a broad variety of services including real estate management, financial management, change management, human resources management, health and safety and contract management, in addition to building maintenance, domestic services (such as cleaning and security) and utilities supplies (Atkin and Brooks, 2000). The most visible of these are the last three services mentioned. The role of FM can be defined as a key function in managing facility resources, support services and the working environment, 
supporting the core business of the organisation from both the long and the short term perspective (Tay and Oi, 2001; Chotipanich, 2004).

Since the late 1980s, FM has gradually gained a foothold as a service discipline and profession within the property and construction industries. Nevertheless, FM is a relatively novel profession (Gilleard et al., 1994; Tay and Ooi, 2001) and its academic research, including related publications, has an even shorter history. Although the 1990s have seen an increase in serious theoretical investigation of FM (Price and Akhalghi, 1999), it still remains under-researched (Nutt, 1999).

In line with general business trends, the FM sector is also "into partnering". However, partnership research undertaken in the field of FM services has been scarce (Lehtonen, 2004; Salonen, 2004), and in business life the term partnering is used rather loosely to refer to a variety of different relationship types (Jones, 1995; Miettinen et al., 2004). On the other hand, procurement and relationship management are apparently becoming increasingly important in academic FM publications (Salonen et al., 2005).

\section{PARTNERSHIP SOURCING}

Over the last few decades, there has been a significant shift in the way organisations approach buyer-seller relationships. Recent years have seen an increased interest in buyersupplier partnerships that tend to be longer, ongoing relationships involving a mutual exchange of ideas, information, and benefits (Ellram, 1995). As market places have become more dynamic and competitive, earlier recommendations for fostering "arm's length relationships" with suppliers in order to avoid dependency and keep prices down have been replaced by emphasizing the potential benefits of close relationships.

The same kind of transition seems to be taking place in the procurement of FM services. Traditionally, relationships between fa- cility service providers and clients have been based on an adversarial approach (Atkin and Brooks, 2000). Services have been purchased separately for single sites and price has been the determining factor in choosing a service provider. As companies continue to outsource non-critical activities and to reduce and trim their supplier bases, existing outsourcing contracts have been expanded and, on the other hand, strategically more important services have been outsourced (Loosemore and Hsin, 2001). Consequently, a need to develop relationships based on a more collaborative approach has arisen (Incognito, 2002), and nowadays few would question the existence of the general trend towards using specialist service providers also in the FM context (Usher, 2004).

Businesses do not enter into partnerships to make friends; they enter into them in order to gain some form of economic reward (Cullen et al., 2000). A company will remain in a partnering relationship insofar as it continues to perceive it as an efficient and equitable organisational form for its purposes (Ârino and Torre, 1998). Normally, inter-firm collaborations contribute to value creation on several levels, including scale economies, the effective management of risk, cost efficient market entries and learning from partners. In addition, partnerships help firms to minimise transaction costs, cope with uncertain environments, reduce their dependence on resources beyond their control, successfully reposition themselves in dynamic markets, share fixed costs, enhance their own core competencies, and acquire access to complementary competencies (e.g. Nooteboom et al., 1997; Ireland et al., 2002). The partnership drivers fall into four categories - asset and cost efficiency, customer service enhancement, marketing advantages, and profit growth or stability (Lambert and Knemeyer, 2004). However, most of these motives are derived from studies on goods or consumer markets and they seem to be slightly different from those associated with services.

It seems reasonable that the nature of exchange depends on the type of service in ques- 
tion. For example: a customised service that is provided during a longer period of time will put emphasis on issues like stability of the supplier, sustainability of the quality of the service delivery process, collaboration aspects, and the matching of the buying firm's demand with the supplier's offer. In contrast, for a standardised service, which is only acquired once or with a low repeat frequency, the emphasis is likely to be on efficiency issues and price. The latter service purchase is of a more transactional nature, whereas the former is characterized by a larger degree of integration and thus has a more relational character (Radkevitch and van der Valk, 2005). Ventovuori et al. (2004) found in their study that in the FM service context, a partnership approach is chosen when the strategic importance of a service is high for the client's or enduser's business, the service to be purchased is complex, there is a need to share sensitive and strategic information or the purchasing volume is large. On the other hand, Lehtonen and Salonen (2005) state that in most cases the choice of the partnership approach in FM services seems to be based solely on the purchasing volume.

In order to increase the purchasing volume, clients are currently forming wider service packages by purchasing services regionally for more than one building at a time, and moving from an adversarial to a collaborative approach in managing their relationships with service providers. This shift is the result of the problems and costs related to managing wide service provider bases using the adversarial approach. By bundling services or sites regionally, benefits are to be gained through the economies of scale. This creates cost advantages, which service providers can convert into corresponding lower prices or higher service levels, novel technologies or innovative structures and procedures (Meneghetti and Chinese, 2002). By reducing and trimming their service provider bases, clients are also trying to trim their FM organisation and alter the job description of in-house FM staff from routine purchas- ing tasks to more strategic tasks including the creation and management of external and internal relationships, which support the overall goals of the company (cf. Kadefors and Bröchner, 2004).

As a result of the re-structuring of buying organisations and supplier bases, a wide variety of different relationship forms has emerged (e.g. Webster, 1992). Guidelines for selecting relationship type usually only identify partnership sourcing and competition as discrete categories (e.g. Macbeth, 1994). However, even casual observation of actual supply relationships reveals that there are different forms of partnership sourcing (e.g. operational and strategic forms) and different forms of competition (e.g. very short-term contracting and long-term competitive contracting) (Parker and Hartley, 1997). Operational partnering refers to working with several suppliers and focusing mainly on the certainty element of the relationship and process elements (Mentzer et al., 2000; Cousins, 2002). The relationship between organisations is strategic when a firm perceives that it needs the relationship in order to be competitive in the industry and that if the partner goes out of business, the firm would have to change its competitive strategy (Johnson, 1999). Based on the discussion above and the results of prior qualitative studies (e.g. Lehtonen and Salonen, 2005; Tuomela et al., 2005), it seems that FM partnerships are intrinsically more operational than strategic.

\section{MANAGING PARTNERING RELATIONS}

While partnerships have the potential to enhance a firm's performance, creating partnerships is challenging because of the difficulties in managing them (Park and Ungson, 2001; Ireland et al., 2002). Working across organisational boundaries is one of the most difficult activities that managers have to accomplish, since it always involves actual or potential problems (Ford et al., 2003; Peng and Kellogg, 2003). Relationship activities are dif- 
ficult to manage due to the differences in organisational goals and structures between companies, the distance involved, the inability to use hierarchies helpful in internal activities, as well as the dynamics of the relationship itself (Ford and Havila, 2003; Sabherwal, 2003).

Gaining benefits from co-operation requires effective management of partnerships (Blumberg, 2001; Ireland et al., 2002). Partners must trust each other not to take advantage of dependencies or chances for opportunistic behaviour. The structuring and control on inter-firm relationships requires the establishment of suitable management control systems and processes (van der Meer-Kooistra and Vosselman, 2000). Different control mechanisms have an impact on different risks or perceived risks. Parties will choose the appropriate partnership control mechanisms based on their risk preference and the provided safeguard (Ring and van de Ven, 1992; Chiles and McMackin, 1996). A recurring source of risk in all transactions is the need to make decisions in the face of the uncertainty of accomplishing tasks that require sustained co-operation with others (Ring and van de Ven, 1992). At the advent of outsourcing and the formation of closer relationships like partnerships, the risk is increasing and shifting around supply networks (Andersson and Norrman, 2003; Harland et al., 2003). This risk will increase as the firms develop closer ties until their operations are truly integrated (Masters et al., 2004).

The problem with partnerships is the problem of creating co-operation among a collection of individuals, units or companies who share only partially congruent objectives. The two dimensions of this partnership problem are, firstly, the creation of conditions that motivate the partners to achieve the desirable or predetermined outcomes and, secondly, the coordination of interdependent tasks between partners (Dekker, 2004). This problem is managed using multiple relationship governance or control mechanisms. Different control mechanisms serve as the building blocks for complex structures of governance that combine elements of markets, hierarchies, and relational exchange in complementary, supplementary, or alternative ways (Cannon et al., 2000).

It is agreed to some extent that all organisational control systems consist of formal as well as social control (Langfield-Smith and Smith, 2003). Formal control consists of contractual obligations and formal organisational mechanisms for co-operation and can be subdivided into outcome and behaviour control mechanisms. Social control, also referred to as relational governance and informal control, is related to informal cultures and systems influencing members and is essentially based on mechanisms that induce self-regulation (Ouchi, 1979). Formal control includes such mechanisms as joint goal setting, planning, command structures, authority systems, incentive systems, standard operating procedures, dispute resolution procedures, and pricing systems. Social control includes the following mechanisms: partner selection, shared values, reciprocity norms, reputations, trust, personal relationships, prior ties, and embeddedness.

Some relationship management control mechanisms have been seen as success factors (Ellram, 1995; Frankel et al., 1996; Whipple and Frankel, 2000) or as creators of competitive advantage (Ireland et al., 2002) for a partnership. In a study covering a broad range of industries, Ellram (1995) found that the five most important factors in a relationship for buyers were: two-way information sharing, top management support, shared goals, early communication to suppliers, and suppliers adding distinctive value. Ireland et al. (2002) studied partnerships from the network perspective and listed the following partnership management mechanisms as having potential for value creation: dedicated relationship management functions, relationship portfolio management, determining the scope, partner selection, compatible strategic intents, and complimentary resources as well as willingness to accommo- 
date a partner's needs, conflict handling and working together at all managerial levels.

However, it is important to note that the relationships that function well in one business environment may not be as successful when transplanted elsewhere (Cox, 1996). Inconsistent logic in value creation results in different levels of interdependence, requiring different degrees of mutual adaptation and adjustment (Borys and Jemison, 1989). In addition, differences in the degree of tangible and intangible elements in service industries compared to manufacturing industries may cause differences between relationship management methods (Leek et al., 2004). Thus, there is reason to expect that the management methods in FM partnerships will also differ to some extent from the management methods delineated in general management literature. Lehtonen and Salonen (2005) found that the success of collaborative relationships between clients and FM providers seems to have some exceptions but is still based on quite similar general management methods, namely, clearly defined and mutually-agreed goals, mutual involvement in relationship development, joint problem solving, two-way information sharing, and the partners' ability to meet performance expectations.

\section{METHODOLOGY}

In order to consolidate earlier relationship research conducted in the field of FM, a descriptive survey needed to be carried out. A questionnaire was developed in order to fulfil this need as well as to gain a deeper understanding of the trends in the procurement of FM services, and for the purposes of investigating the respective importance of different management methods or success factors in establishing and maintaining partnering relationships. The target group of the questionnaire were companies buying FM services (i.e. user or user-owner company, real estate investor, property management company). In this study, FM services refer to real estate mainte- nance, technical maintenance, cleaning, grounds maintenance and waste management. In the questionnaire, a partnering relation was understood as a mutually beneficial relationship in which both parties are committed in the long-term to develop and maintain this two-way relationship (cf. Ellram, 1995).

The questionnaire was divided to four parts. The first two parts covered the procurement of FM services. The first part of the questionnaire consisted of questions related to purchasing management and the second part of questions related to transitions in service procurement practices. The last two parts were concerned with the partnering approach adopted. There were questions about motives and circumstances for partnership sourcing, and in the last part the success factors of partnering relationship were investigated.

The first draft of the questionnaire was developed by the authors based on their previous studies. The precise wording of the questions was tailored to fit the FM context in collaboration with industry experts. The purpose of this collaboration was to develop a set of items that tap each of the relevant topics and to provide an initial test of some of the measures chosen. To be precise, the first version was modified in cooperation with representatives from RAKLI (The Finnish Association of Building Owners and Construction Clients), an interest group and trade association representing the most prominent real estate owners, investors and service providers in Finland. Based on their recommendations, a few questions were removed and some were modified. The next version was piloted with the Senior Vice President of a Finnish real estate investment company. Based on his comments, one question was added for the final version of the questionnaire.

The internet-based questionnaire was carried out in co-operation with RAKLI. The questionnaire was sent to the 50 most important buyers in the Finnish FM market. The buyers represented both public and private organisations. This was considered to cover 
extensively the Finnish FM market, especially as the focus of the study was partnership sourcing.

The importance of buyers was determined using the following approximations of importance: firstly, the amount of space owned (in square metres), and secondly, for management companies, the turnover, and for municipalities the size of the population. The identification of key sample respondents was based on information in the database of RAKLI. The database contains information about the buyers of FM services and persons responsible for decisions related to relationships with FM service providers. The key respondents were contacted via email and asked to respond to the survey. In order to improve the response rate, the importance of the survey for RAKLI and for the development of the FM industry was emphasized. Initially, the survey rendered 19 responses, and after one week of the first contact a reminder was sent to those 31 respondents who had not yet responded. The total response rate was $66 \%$.

The questionnaire was filled in anonymously. To questions related to the procurement trends, respondents were asked to answer either yes or no. In relationship management questions, they were asked to rate the importance of different factors on a 5-point scale (from strongly agree to disagree) and after that to choose the most important factor of the group.

\section{RESULTS}

The results mainly support observations from earlier qualitative studies carried out in the field of FM. Nevertheless, they include many interesting and even surprising observations. In this section, the results are described and discussed further. The following section comprises some conclusions drawn based on the results.

According to our data, the use of partnership sourcing is a growing trend also in FM services. The results show that $67 \%$ of buyers have established or aim to establish a close partnering relationship with one or several FM service providers. Interestingly, however, over half of the buyer organisations (64\%) did not have a sourcing strategy for FM services, which is usually used as the basis for the choice of relationship type. $77 \%$ of those who used the partnership approach had increased purchasing volume by bundling multiple sites to one service provider, whereas this strategy had only been employed by $45 \%$ of the adversarial approach users. When analysing the use of the method of increasing purchasing volume via bundling of different services to one service provider, we found that $68 \%$ of partnership proponents used this technique for one or more sites. On the other hand, only $27 \%$ of users of the adversarial approach had used bundling of services for one or multiple sites. Based on this, it seems that wider service packages are positively related to partnership sourcing in the context of FM. The primary way of increasing purchasing volume was found to be the bundling of a specific service in multiple sites to one service provider (67\% of all buyers had used this during the last five years) compared to the bundling of different services to one service provider (15\% had used this at a one site and $39 \%$ had formed multi-site bundled service packages).

While the reduction of the supplier base is usually associated with the partnering approach, this does not seem to be the case in the context of FM. While $33 \%$ of respondents had reduced the number of their partners, $21 \%$ did not undergo such changes, and $45 \%$ had increased their supplier base. Hence, the overall number of supplier bases was, in fact, increasing. This might be the case because $67 \%$ of the buyers had outsourced a growing number of their facilities related functions during the last five years. However, $82 \%$ of the buyers who had reduced their supplier base had increased their outsourcing during the same period. Despite the general growth of the supplier base, buyers still seemed to be able to reduce their in-house staff (this was true for 
$33 \%$ of all respondents). A more thorough analysis of the data revealed that $64 \%$ of those who had reduced the number of suppliers had also reduced the number of in-house staff, while $47 \%$ of those who had expanded their supplier base had also expanded their in-house staff. Thus, it would seem that reducing the number of service providers makes it possible to re-structure and trim FM organisations.

One of the main findings of the survey is that FM partnerships have some specific characteristics, and there seem to be differences between FM and general partnerships (i.e. those related to supply chain management). We defined partnerships to be mutually beneficial relationships in which both parties are committed in the long term to the development and maintenance of this two-way relationship. However, our data does not support the generalisation of this view to FM partnerships.

Firstly, partnerships in Finnish FM are formed in order to gain improvements in quality and further the development of activities and processes. Nonetheless, in contrast to the motives for forming the partnership, the choice of partner is based mainly on price and prior experiences of working with the supplier in question. Especially the first criterion differs from generally established decision-making criteria, e.g. the perceived potential for long-term improvement, the compatibility of partners and a shared vision. Thus, it seems that the drivers for FM partnerships are distinct from those mentioned in the context of traditional supply chain management.

Secondly, the ongoing co-operation on the strategic level was not seen as important for the success of a partnership. This deviates from the prevailing philosophy, which holds that partners should have a strong organisational fit. However, the initial strategic level input realized in setting up the mutual vision and values for the partnership was perceived as an important management mechanism to ensure partnership success.

Thirdly, in Finnish FM partnership benefits gained from the relationship are usually not shared proportionally with respect to the investments by the various parties, nor is risk sharing perceived as an essential part of partnering. Besides the lack of risk sharing initiatives, parties do not have formalised risk management methods related to the alliance risk. According to our data, only $9 \%$ of respondents had a clearly stated risk management procedure.

Fourthly, our findings do not support the assumption that partnership sourcing would result in longer-term contracts. Only $33 \%$ of buyers practicing partnership sourcing reported utilizing longer contract periods, while $61 \%$ of all buyers reported that the length of contracts had not changed.

Summarising the unique characteristics of (Finnish) FM partnerships, the following might be stated: top management (i.e. strategic level) establishes shared values and visions. Once they have introduced these to the organisation they do not have any significant role in the partnership. During the ongoing partnership, the operational level runs the daily initiative, development and problem solving based on ad hoc procedure.

It was expected that as FM partnerships would differ from those found in literature and have their unique characteristics, the management of these would also be different to some extent. In an earlier multiple-case study (Lehtonen and Salonen, 2005), it was found that the successful FM partnership is managed by the following relationship management mechanisms: (a) clearly defined and mutually agreed goals, (b) mutual involvement in relationship development, (c) joint problem solving, (d) two-way information sharing, and (e) the partners' ability to meet performance expectations. In order to analyse this statement, several sub-constructs for each management method were used (Table 1).

The first management method, implementing clearly defined and mutually agreed goals, was studied using two sub-constructs: partners have shared visions and values (average value of 4.39) and partners have mutually-agreed 
Table 1. Success factors of FM partnerships

\begin{tabular}{ll}
\hline Clearly defined and mutually agreed goals & 4.39 \\
Partners have shared visions and values & 4.58 \\
Partners have mutually-agreed upon goals for the relationship & 3.79 \\
Mutual involvement & 4.33 \\
Joint planning & 4.27 \\
Mutual relationship development & \\
Joint problem solving & 3.81 \\
Two-way information sharing & 3.69 \\
Reporting between parties is systematic & 3.19 \\
Content, frequency and participants of various meetings are defined & 3.75 \\
Meetings between the top management of the companies & 4.54 \\
Managerial level meetings & \\
Operational level meetings & 4.36 \\
Partners' ability to meet performance expectations & 4.32 \\
Service provider takes care of problems related to its subcontractors & 4.24 \\
Service provider takes care of advising new service employees & 4.14 \\
Sufficient technical know-how and skills of service employees & \\
Accomplishment of the goals is monitored and goals are updated if required &
\end{tabular}

upon goals for the relationship (average value of 4.58). The values for the sub-constructs indicate that the mutually agreed goals are important for partnership success in the context of FM.

Mutual involvement was studied with two sub-constructs: joint planning (3.79) and mutual relationship development (4.33). According to the data, it is important that both parties collaboratively participate in the relationship development. However, the findings of the survey did not support the assumption that joint planning would be important for partnership success. Interestingly, the other aspect of joint action, namely, joint problem solving (4.27), was found to be important for management mechanisms.

Two-way information sharing included altogether five sub-constructs in two sets. The first set comprised two questions related to systematic information sharing: partners have defined what kind of information is shared, how often, and who is responsible for collecting the data (3.81) and partners have defined the content and frequency of different types of meetings and defined which organisational levels participate in these meetings (3.69). The second set comprised three questions covering interaction between different organisational levels. Firstly, there are meetings between the top management of the companies. The aim of these meetings is to set mutual strategic longterm goals and to try to discover the potential synergies between the operations of the service provider and the client (3.19). Secondly, the managerial levels of companies hold meetings where the aim is to develop the operations related to the relationship (3.75). Lastly, there are operational level meetings for adopting new courses of action and for solving practical problems related to service providing (4.54). Thus, it seems that only operational level meetings are deemed important in terms of the success of FM partnerships. This finding is in line with the operational nature of the studied FM services.

The partners' ability to meet performance expectations was studied with the following four sub-constructs: service provider takes care of problems related to its subcontractors (4.36), 
service provider takes care of advising new service employees (4.32), service employees have the technical know-how and skills needed to provide service (4.24) and the accomplishment of the goals is monitored and goals are updated if required (4.14). The values for these sub-constructs indicate that the partner's ability to meet performance expectations is seen as an important part of successful FM partnerships.

In addition to the above mentioned management mechanisms, we discovered the emerging importance of front-line staff's capability to provide friendly customer service, and positive feedback from end-users. Previous qualitative studies have made corresponding findings. The reason is probably that FM services are delivered on the premises of the client and thus the impact of end-users on the success of the relationship is perceived to be significant.

\section{CONCLUSIONS}

This study has attempted to clarify the procurement and relationship management trends in business services, particularly in the FM setting in Finland. It was discovered that a transition towards closer relationships and bigger purchase entities is taking place in FM similarly to other industries. However, some exceptions were also identified. These exceptions might be explained partly by the novelty of the partnering phenomenon in the FM context and partly by the highly operational nature of most FM services.

Since the formation and maintenance of partnerships are costly and time-consuming processes, organisations should become involved in them only after rigorously conducted strategic analyses. However, there is a gap between theory and industrial practice as only few organisations have a sourcing strategy for FM services. In the future, companies should evaluate each sourcing situation more thoroughly and decide which relationship type to apply.
In contrast to the prevailing trends in other industries, there was an increase in the size of supplier bases in FM. This might be partly due to organisations outsourcing more of their facilities-related functions during the recent years and partly due to the shift from using a sole supplier to using a number of specialist partners. The general lack of sourcing strategies supports the fact that the outsourcing and procurement practices of FM services are still in their transformation phase.

Since organisations have not yet fully recognised the importance of the relational risk or formalised their management mechanisms for providing services in closer relationships, there exists a strong potential for them in taking advantage of and adopting relational risk management schemes as well as more sophisticated relationship management methods which are already used widely in the more matured industries. In addition to the business perspective, relationship success in FM services includes the end-user perspective, which emphasises the importance of site-level operations. This, alongside with the fact that FM services account for only minor proportion of strategic corporate value, could also explain why little attention is paid to the management of FM partnering relationships at the strategic level of the company.

This study may also be beneficial for service providers in terms of formulating successful relationships and managing buyers' perception of service quality. Firstly, as partnerships yield competitive advantage only through effective management, suppliers should exploit the success factors mentioned here. Secondly, suppliers may reap the potential benefits of partnerships fulfilling buyer expectations by focusing on their front-line staff's friendliness and ensuring good enduser feedback.

Altogether, the study contributes to the relationship management literature from the business services point of view. The results could prove to be useful for both service providers and buyer organisations in improving 
the performance and efficiency of partnering relationship. However, some limitations should be recognised and taken into account when interpreting our findings.

\section{LIMITATIONS AND FURTHER RESEARCH}

The results of the study may be applied to other business services to some extent, particularly to support services, which are operational by nature. However, it is important to note that the relationships which work successfully in one business environment may not be as successful when transplanted elsewhere.

The results should not be freely generalized due to four reasons. The first reason is that the study was carried out only in a single country. Thus, differences between markets could not be observed.

The second limitation is related to our sample. Even though our response rate was exceptionally high, attention should be paid to the possible effects of non-response. On the other hand, although the sample covers the Finnish FM service market extensively, it is still quite small from a statistical point of view. Due to the data capture methods used, we were not able to analyse the possible differences in the answers of the early and late respondents. Moreover, the sample of respondents comprised mainly of large companies who are members of RAKLI. Therefore, the study sample may be somewhat skewed toward companies with proactive facilities management.

The third reason is that the data was gathered only from the buyer side of the dyadic relationship. It has been noted in the literature that the emphasis on each control mechanism differs between suppliers and buyers (cf. Leek et al., 2004).

Lastly, FM relationships (in Finland) are often buyer-dominated. Consequently, further research should use the same questionnaire in different business environments. Furthermore, in order to be able to make stronger claims to support the supposition that particular gover- nance mechanisms result in partnership success, one should conduct an extensive test including the effect of the mechanisms on the partnerships' performance (cf. Cannon et al., 2000).

\section{REFERENCES}

Andersson, D. and Norrman, A. (2003) Managing risk when outsourcing advanced logistics, in Proceedings of the 12th International IPSERA Conference, p. 377-391.

Amaratunga, D., Baldry, D. and Sarshar, M. (2000) Assessment of facilities management performance - What next?, Facilities, 18(1/2), p. 6675 .

Amaratunga, D. and Baldry, D. (2002) Performance measurement in facilities management and its relationships with management and motivation, Facilities, 20(10) p. 327-336.

Atkin, B. and Brooks, A. (2000) Total facilities management, Oxford: Blackwell Science.

Ãrino, A. and Torre, J. (1998) Learning from failure: Towards an evolutionary model of collaborative ventures, Organization Science, 9(3), p. 306-325.

Arnold, U. (2000) New dimensions of outsourcing: A combination of transaction cost economics and the core competencies concept, European Journal of Purchasing \& Supply Management, 6(1), p. 23-29.

Balch, W.F. (1994) An integrated approach to property and facilities management, Facilities, 12(1), p. 17-22.

Blumberg, B.F. (2001) Cooperation contracts between embedded firms, Organization Studies, 22(5), p. 825-852.

Bon, R., McMahan, J.F. and Carder, P. (1998) Property performance measurement: From theory to management practice, Facilities, 16(7/8), p. 208-214.

Borys, B. and Jemison, D.B. (1989) Hybrid arrangements as strategic alliances: Theoretical issues in organizational combinations, Academy of Management Review, 14(2), p. 234-249.

Bröchner, J. (2001) Facilities management as a special case of business service management," in Leväinen, K.I. (ed.), Facility management and service concepts - International research seminar on real estate management 29th to 30th 
March 2001, Helsinki University of Technology, p. 12-18.

Cannon, J., Achrol, R. and Gundlach, G. (2000) Contracts, norms, and plural form governance, Academy of Marketing Science, 28(2), p. 180194.

Chiles, T., and McMackin, J. (1996) Integrating variable risk preferences, trust, and transaction cost economics, Academy of Management Review, 21(1), p. 73-99.

Chilton, J.J. and Baldry, T. (1997) The effects of integrated workplace strategies on commercial office space, Facilities, 15(7), p. 187-194.

Chotipanich, S. (2004) Positioning facilities management, Facilities, 22(13/14), p. 364-372.

Cousins, P.D. (2002) A conceptual model for managing long-term inter-organisational relationships, European Journal of Purchasing \& Supply Management, 8(2), p. 71-82.

Cox, A. (1996) Relational competence and strategic procurement management - Towards an entrepreneurial and contractual theory of the firm, European Journal of Purchasing \& Supply Management, 2(1), p. 57-70.

Cullen, J., Johnson, J. and Sakano, T. (2000) Success through commitment and trust: The soft side of strategic alliance management, Journal of World Business, 35(3), p. 223-240.

Dekker, H.C. (2004) Control of inter-organizational relationships: Evidence on appropriation concerns and coordination requirements, Accounting, Organizations and Society, 29(1), p. 2749.

El-Haram, M.A. and Agapiou, A. (2002) The role of the facility manager in new procurement routes, Journal of Quality in Maintenance Engineering, 8(2), p. 124-134.

Ellram, L.M. (1991) A managerial guideline for the development and implementation of purchasing partnerships, International Journal of Purchasing and Materials Management, 27(3), p. 2-8.

Ellram, L.M. (1995) Partnering pitfalls and success factors, International Journal of Purchasing and Materials Management, 31(2), p. 36-44.

Ellram, L.M., Tate, W.L. and Billington, C. (2004) Understanding and managing the services supply chain, Journal of Supply Chain Management, 40(4), p. 17-32.

Fearon, H.E. and Bales, W.A. (1995) Purchasing of nontraditional goods and services. Tempe, AZ:
Center for Advanced Purchasing Studies.

Fitzsimmons, J.A., Noh, J. and Thies, E. (1998) Purchasing business services, Journal of Business \& Industrial Marketing, 13(4/5), p. 370380 .

Ford, D., Gadde, L.E., Håkansson, H. and Snehota, I. (2003) Managing business relationships, 2nd edition, Chichester: John Wiley \& Sons.

Ford, D. and Havila, V. (2003) Problems in relationships: When it all goes wrong, in Proceedings of the 19th Annual IMP Conference.

Frankel, R., Whipple, J.S. and Frayer, D.J. (1996) Formal versus informal contracts: Achieving alliance success, Industrial Journal of Physical Distribution \& Logistics Management, 26(3), p. 47-63.

Gajendran, T. and Sabaratnam, R. (2002) An integrated approach to assess facilities performance, in Proceedings of the CIB W70 Glasgow Symposium, p. 183-194.

Gilleard, D., Chan, M.W., Ratcliffe, J. and Pilling, E. (1994) The impact of facilities management in Hong Kong, in Proceedings of the CIB W7O Tokyo Symposium, p. 151-158.

Grönroos, C. (2000) Service management and marketing - A customer relationship management approach, 2nd edition, Chichester: John Wiley \& Sons.

Harland, C., Brenchley, R. and Walker, H. (2003) Risk in supply networks, Journal of Purchasing \& Supply Management, 9(2), p. 51-62.

Incognito, J.D. (2002) Outsourcing - Ensuring survival with strategic global partners, Journal of Facilities Management, 1(1), p. 7-15.

Ireland, R., Hitt, M. and Vaidyanath, D. (2002) Alliance management as a source of competitive advantage, Journal of Management, 28(3), p. 413-446.

Johnson, J.L. (1999) Strategic integration in industrial distribution channels: Managing the interfirm relationship as a strategic asset, Journal of the Academy of Marketing Science, 27(1), p. 4-18.

Jones, O. (1995) Corporate partnering in facilities management, Facilities, 13(13), p. 21-26.

Kadefors, A. and Bröchner, J. (2004) Building users, owners and service providers: New relations and their effects, Facilities, 22(11/12), p. 278-283.

Kincaid, D. (1994) Measuring performance in facility management, Facilities, 12(6), p. 17-20. 
Lambert, D.M. and Knemeyer, A.M. (2004) We're in this together, Harvard Business Review, 82(12), p. 114-122.

Landeros, R., Reck, R. and Plank, R.E. (1995) Maintaining buyer-supplier partnerships, International Journal of Purchasing and Materials Management, 31(3), p. 3-11.

Langfield-Smith, K. and Smith, D. (2003) Management control systems and trust in outsourcing relationships, Management Accounting Research, 14(3), p. 281-307.

Leek, S., Turnbull, P. and Naudé, P. (2004) A comparison of manufactures and financial services suppliers' and buyers' use of relationship management methods, Industrial Marketing Management, 33(3), p. 241-249.

Lehtonen, T. (2004) Attributes and success factors of partnering relations - A theoretical framework for facility services, Nordic Journal of Surveying and Real Estate Research - Special Series, 2, p. 31-46.

Lehtonen, T. and Salonen, A. (2005) Attributes and success factors of collaborative relationships: A case study in facility services, in Proceedings of the 14th IPSERA Conference, p. 709-719.

Loosemore, M. and Hsin, Y.Y. (2001) Customer-focused benchmarking for facilities management, Facilities, 19(13/14), p. 464-475.

Macbeth, D.K. (1994) The role of purchasing in a partnering relationship, European Journal of Purchasing and Supply Management, 1(1), p. 19-25.

Masters, J.K., Miles, G., D’Souza, D. and Orr, J.P. (2004) Risk propensity, trust, and transaction costs in relational contracting, Journal of Business Strategies, 21(1), p. 47-67.

van der Meer-Kooistra, J. and Vosselman, E. (2000) Management control of interfirm transactional relationship: The case of industrial renovation and maintenance, Accounting, Organisations and Society, 25(1), p. 51-77.

Meneghetti, A. and Chinese, D. (2002) Perspectives on facilities management for industrial districts, Facilities, 20 (10), p. 337-348.

Mentzer, J.T., Min, S. and Zacharia, Z.G. (2000) The nature of interfirm partnering in supply chain management, Journal of Retailing, 76(4), p. 549-568.

Miettinen, I., Ventovuori, T. and Lehtonen, T. (2004) Identifying the enablers of partnering: A case study in facility services, in Proceedings of the 3rd European Research Symposium in Facilities Management, p. 113-120.

Nooteboom, B., Berger, H. and Noorderhaven, N. (1997) Effects of trust and governance on relational risk, Academy of Management Journal, 40(2), p. 308-338.

Nutt, B. (1999) Linking FM practice and research, Facilities, 17(1/2), p. 11-17.

Ouchi, W.G. (1979) A conceptual framework for the design of organizational control mechanisms, Management Science, 25(9), p. 833-848.

Park, S. and Ungson, G. (2001) Interfirm rivalry and managerial complexity: A conceptual framework of alliance failure, Organization Science, 12(1), p. 37-53.

Parker, D. and Hartley, K. (1997) The economics of partnership sourcing versus adversarial competition: A critique, European Journal of Purchasing \& Supply Management, 3(2), p. 115125.

Peng, T.-J. and Kellogg, J.L. (2003) Partners, resources, and management mechanisms of inter-organizational collaborative ties in nonprofit organizations, Journal of American Academy of Business, 3(1/2), p. 291-298.

Price, I. and Akhlaghi, F. (1999) New patterns in facilities management: Industry best practice and new organisational theory, Facilities, 17(5/ 6), p. 159-166.

Radkevitch, U. and van der Valk, W. (2005) Buying business services through auctions: From transactional to a relational approach, in Proceedings of 14th IPSERA Conference, p. 851-863.

Ring, P. and van de Ven, A.H. (1992) Structuring cooperative relationships, Strategic Management Journal, 13(7), p. 483-498.

Sabherwal, R. (2003) The evolution of coordination in outsourced software development projects: A comparison of client and vendor perspectives, Information and organization, 13(3), p. 153202.

Salonen, A. (2004) Managing outsourced support services: Observations from case study, Facilities, 22(11/12), p. 317-322.

Salonen, A., Lehtonen, T. and Ventovuori, T. (2005) A review and classification of empirical research in facilities management, in Proceedings of the 4th European Research Symposium in Facilities Management, p. 477-485.

Sheth, J.N. and A. Sharma (1997) Supplier relationships - Emerging issues and challenges, 
Industrial Marketing Management, 26(2), p. 91-100.

Smeltzer, L.R. and Ogden, J.A. (2002) Purchasing professionals' perceived differences between purchasing materials and purchasing services, Journal of Supply Chain Management, 38(1), p. 54-70.

Tay, L. and Oi, J.T.L. (2001) Facilities management: A “Jack of all trades"?, Facilities, 19(10), p. 357363.

Tuomela, A., Heimbürger, M., Nummi, J. and Toivonen, J. (2005) Interaction in a building owner centred network - Case study, Facilities, 23(9/10), p. 373-392.

Usher, N. (2004) Outsource or in-house facilities management: The pros and cons, Journal of Facilities Management, 2(4), p. 351-359.

van der Valk, W., Wynstra, F. and Axelsson, B. (2005) The trouble with purchasing services, in Proceedings of the 14th IPSERA Conference, p. 1033-1045.

Ventovuori, T., Lehtonen, T. and Miettinen, I. (2004) Selecting relationship type in facility services," in Proceedings of the CIB W70 Hong Kong International Symposium, p. 385-393.

Virolainen, V.-M. (1998) Motives, circumstances, and success factors in partnership sourcing, doctoral dissertation, Lappeenranta University of Technology.

Webster, F.E. Jr. (1992) The changing role of marketing in the corporation, Journal of Marketing, 56(4), p. 1-17.

Whipple, J.M. and Frankel, R. (2000) Strategic alliance success factors, Journal of Supply Chain Management, 36(3), p. 21-28.

Yik, F. and Lai, J. (2005) The trend of outsourcing for building services operation and maintenance in Hong Kong, Facilities, 23(1/2), p. 63-72.

\section{SANTRAUKA}

\section{PIRKIMŲ TENDENCIJŲ IR PARTNERYSTĖS VALDYMO PŪV PASLAUGŲ SEKTORIUJE EMPIRINIS TYRIMAS: APKLAUSA SUOMIJOJE}

\section{Tero LEHTONEN, Anssi SALONEN}

Šio darbo tikslas - apžvelgti pastatų ūkio valdymo (PŪV) paslaugų pirkimo tendencijas ir aprašyti partnerystės kontrolès mechanizmus, kurie prisideda prie PŪV partnerystės sėkmės. Tyrimas pagrịstas Suomijoje atlikta apklausa. Išsiaiškinta, kad artimesnių santykių palaikymas ir stambesnių pirkimų objektų paieška vyksta ir PŪV kontekste. Daugeliu atvejų partnerystę renkamasi kuriant didesnius paslaugų paketus. Igyvendinant partneriškus santykius, aukščiausio lygmens vadovų uždavinys - pristatyti bendras vertybes ir vizijas. Nustačius jas organizacijoje, aukščiausi vadovai lyg ir nebeturi reikšmingo vaidmens valdant santykius. Nuolatinè partnerystė sudaro sąlygas operatyviniu lygmeniu rūpintis kasdienèmis iniciatyvomis, raida ir problemų sprendimu, pagrịstu specialiomis procedūromis. 